\title{
PENDAPATAN ASLI DAERAH SEKTOR KEHUTANAN PADA ERA OTONOMI DAERAH DI KABUPATEN MUNA
}

\author{
Local Goverment Revenue of Forestry Sector in The Regional Autonomy Era in Muna District
}

\author{
A. Mujetahid ${ }^{\bowtie}$ \\ Lab. Pemanenan Hasil Hutan, Fakultas Kehutanan Universitas Hasanuddin, \\ Jl. Perintis Kemerdekaan Km. 10 Tamalanrea, Makassar 90245
}

\begin{abstract}
This research was aimed to know contribution of forestry sector to Local Government Revenue at district of Muna in regional autonomy era. The research result is expected to contribute in evaluating and compiling Regional Budget and Expenditure Plan. The result is also intended as an evaluation of forest product restribution policy. Data were collected with purpossive sampling using observation technique/survey, interview and discussion with related stakeholders. The data was then processed, tabulated, clasified base on with research aim, and analysed descriptively. The results show that the contribution of forestry sector to Local Government Revenue to Muna district during 2000-2004 in average was $36.77 \%$ of Local Government Revenue in total.
\end{abstract}

Key words: contribution, forestry sector, Local Government Revenue, regional autonomy

\section{PENDAHULUAN}

Secara yuridis, Undang-undang (UU) Nomor 41 tahun 1999 tentang Kehutanan merupakan acuan pokok dalam penyelenggaraan kehutanan, baik tingkat pusat, provinsi maupun daerah (kabupaten/kota). Hal ini bertujuan untuk menjamin keberadaan hutan, optimalisasi fungsi hutan serta distribusi manfaat secara adil dan berkelanjutan. Dalam prakteknya, pelaksanaan undang-undang tersebut seringkali tidak sinkron dengan UU Nomor 32 tahun 2004 tentang Pemerintah Daerah, karena UU Nomor 41 tahun 1999 tentang Kehutanan lebih menitikberatkan kepada aspek-aspek pengelolaan hutan yang ideal. Pada sisi lain UU Nomor 32 tahun 2004 tentang Pemerintah Daerah, lebih menitikberatkan kepada pembagian kewenangan antara pemerintah pusat dan daerah.

Kondisi awal dari perjalanan otonomi daerah tersebut, menunjukkan bahwa, ternyata berbagai persoalan yang ada menyangkut upaya sebagian PemerintahDaerahuntukmeningkatkanPendapatan

Diterima: 16 Agustus 2011; Disetujui: 15 Desember 2011

$\square$ Penulis korespondensi (corresponding author): mujetahid.unhas@yahoo.co.id
Asli Daerah (PAD). Situasi ini menimbulkan tekanan bagi Pemerintah Daerah untuk menghasilkan tambahan pendapatan dengan mengenakan pajak dan retribusi baru. Salah satu sektor yang diharapkan dapat memberikan kontribusi terhadap PAD adalah sektor kehutanan. Dengan otonomi daerah, pengelolaan sumberdaya hutan diharapkan lebih demokratis dan hasilnya langsung dapat dinikmati oleh daerah secara lebih merata. Namun di sisi lain ada pihak yang mengkhawatirkan jika otonomi daerah dipahami sekedar kesempatan sebesarbesarnya bagi daerah untuk mengeksploitasi sumberdaya hutan guna meningkatkan PAD.

Pemerintah Daerah berusaha memacu pemasukan bagi PAD dari berbagai sektor di wilayahnya termasuk di dalam sektor kehutanan. Mengacu kepada Undang-undang Nomor 25 tahun 1999 tentang Perimbangan Keuangan antara Pemerintah Pusat dan Daerah, maka pemerintah daerah tidak saja berhak mengelola sumberdaya hutan di wilayahnya, namun juga harus bertanggung jawab memelihara kelestarian sumberdaya tersebut. Jika tidak dikelola dengan baik, maka kelestarian sumberdaya hutan akan sulit diwujudkan.

Berdasarkan latar belakang dan permasalahan yang telah dikemukakan pada bagian terdahulu, maka tujuan yang ingin dicapai dalam penelitian 
ini adalah untuk mengetahui kontribusi sektor kehutanan terhadap PAD di Kabupaten Muna di era otonomi daerah dan untuk mengetahui jenis-jenis pungutan yang memberikan kontribusi terhadap PAD di era otonomi daerah tersebut.

Hasil yang diharapkan sebagai keluaran dari penelitian ini adalah tersedianya data dan informasi tentang besarnya kontribusi sektor kehutanan terhadap PAD Kabupaten Muna, sehingga pemerintah kabupaten dapat mengelola hutan dengan baik karena memberikan kontribusi yang signifikan terhadap PAD.

\section{BAHAN DAN METODE}

Penelitian ini dilaksanakan di Kabupaten Muna Propinsi Sulawesi Tenggara. Lokasi tersebut dipilih karena Kabupaten Muna memiliki kawasan hutan yang luas yaitu 235.759 ha dibandingkan dengan luas wilayahnya yaitu 488.700 ha $(48,24$ $\%)$.

Pengumpulan data dilakukan dengan teknik observasi/survei, wawancara dan diskusi dengan stakeholder yang ada kaitannya dengan penelitian ini (purposive sampling). Data yang telah dikumpulkan selanjutnya diolah, ditabulasi dan diklasifikasikan sesuai dengan tujuan penelitian, selanjutnya dianalisis dengan menggunakan formula sebagai berikut:

a. Persentase realisasi penerimaan sektor kehutanan

Realisasi Penerimaan Sektor Kehutanan x $100 \%$ Target Penerimaan Sektor Kehutanan

b. Persentase kontribusi sektor kehutanan terhadap PAD $\frac{\text { Total Penerimaan Sektor Kehutanan }}{\text { Total Realisasi Penerimaan PAD }} 100 \%$

c. Persentase realisasi penerimaan PAD

$\frac{\text { Realisasi Penerimaan PAD }}{\text { Target Penerimaan PAD }} \times 100 \%$

d. Penerimaan PSDH Kabupaten Muna

$32 \%$ x Jumlah setoran

\section{HASIL DAN PEMBAHASAN}

\section{Jenis Penerimaan}

Jenis penerimaan dalam sektor kehutanan di Kabupaten Muna dibedakan atas penerimaan berdasarkan dana bagi hasil antara pemerintah pusat dan daerah serta penerimaan pendapatan daerah murni berdasarkan peraturan daerah (setelah otonomi daerah) dan penjualan lelang kayu jati.

\section{Penerimaan Bagi Hasil Pemerintah Pusat dan Daerah}

Dana bagi hasil antara pemerintah pusat dan daerah diatur dalam UU No 33 tahun 2004. Dana bagi hasil tersebut berupa Provisi Sumberdaya Hutan (PSDH) dan Dana Reboisasi (DR) masingmasing sebesar $32 \%$ dan $40 \%$ dari setoran, akan dikembalikan ke daerah penghasil.

\section{Penerimaan Pendapatan Daerah Murni}

Daerah otonom adalah kesatuan masyarakat hukum yang mempunyai batas daerah tertentu berwenang mengatur dan mengurus kepentingan masyarakat setempat menurut prakarsa sendiri berdasarkan aspirasi masyarakat dalam ikatan Negara Kesatuan Republik Indonesia. Pilihanpilihan daerah otonom dapat dilaksanakan pada daerah propinsi dan kabupaten. Salah satu kewenangan yang akan dilaksanakan oleh pemerintah daerah kabupaten dan propinsi adalah kewenangan pengelolaan sumberdaya nasional yang tersedia di wilayahnya dan bertanggung jawab memelihara kelestarian lingkungan sesuai dengan peraturan perundang-undangan (pasal 10 ayat 1), walaupun dalam pasal 7 ayat (2) UU No. 22 tahun 1999 disebutkan pemerintah (pusat) masih memiliki kewenangan tentang pendayagunaan sumberdaya alam yang strategis.

Penerimaan pendapatan daerah murni terbagi atas pendapatan yang diperoleh berdasarkan peraturan daerah dan hasil penjualan lelang kayu jati.

\section{Peraturan Daerah Kabupaten Muna}

Sebagai wujud nyata pelaksanaan otonomi daerah dalam upaya meningkatkan pertumbuhan perekonomian daerah, maka pemerintah daerah mengeluarkan peraturan daerah menambah sumber pendapatan khususnya bidang kehutanan. Peraturan daerah yang telah ditetapkan adalah:

\section{a. Perda Nomor 2 Tahun 2002 tentang Retribusi ljin Pemungutan Hasil Hutan Kayu dan Bukan Kayu pada Hutan Alam Produksi (IPHHK dan IPHHBK)}

Secara garis besar, perda ini mengatur tentang tata cara permohonan perijinan, tata cara 
Tabel 1. Jumlah tarif IPKTM berdasarkan jenis kayu gergajian

\begin{tabular}{|c|c|c|c|}
\hline No. & Deskripsi & Jenis Kayu Gergajian & Tarif $\left(\operatorname{Rp} \times 1.000 \mathrm{~m}^{-3}\right)$ \\
\hline \multirow[t]{3}{*}{1} & Jati Hasil Budidaya & a. Sortimen A I & 50 \\
\hline & & b. Sortimen A II & 75 \\
\hline & & c. Sortimen A III & 150 \\
\hline \multirow[t]{3}{*}{2} & Jati Bukan Hasil Budidaya & a. Sortimen A I & 75 \\
\hline & & b. Sortimen A II & 150 \\
\hline & & c. Sortimen A III & 300 \\
\hline
\end{tabular}

pemungutan retribusi, tata cara pembayaran dan sanksi-sanksi yang akan diberikan apabila terjadi penyimpangan. Dengan ditetapkannya perda ini tanggal 20 Pebruari 2002, maka pengurusan perijinan tidak dilaksanakan di Dinas Kehutanan Propinsi Sulawesi Tenggara, tetapi di Dinas Kehutanan Kabupaten Muna. Besarnya tarif retribusi IPHHK ditetapkan sebesar Rp $500.000 \mathrm{ha}^{-1}$ dan besarnya retribusi IPHHBK ditetapkan sebesar Rp 100.000 ha $^{-1}$.

\section{b. Perda Nomor 3 Tahun 2002 tentang Retribusi ljin Pemanfaatan Kayu (IPK)}

Secara garis besar, perda ini mengatur tentang tata cara permohonan perijinan, tata cara pemungutan retribusi, tata cara pembayaran dan sanksi-sanksi yang akan diberikan apabila terjadi penyimpangan. Dengan ditetapkannya perda ini tanggal 20 Pebruari 2002, maka pengurusan perijinan tidak dilaksanakan di Dinas Kehutanan Propinsi Sulawesi Tenggara, tetapi di Dinas Kehutanan Kabupaten Muna. Besarnya tarif retribusi IPK ditetapkan sebesar Rp 500.000 ha-1. $^{-1}$

\section{c. Perda Nomor 4 Tahun 2002 tentang ljin Pemungutan Kayu (IPK) pada IPKTM}

Secara garis besar, perda ini mengatur tentang tata cara permohonan perijinan, hak dan kewajiban pemegang ijin, tata cara pemungutan retribusi, tata cara pembayaran dan sanksi-sanksi yang akan diberikan apabila terjadi penyimpangan. Perda ini ditetapkannya pada tanggal 20 Pebruari 2002. Terbitnya perda ini didasari oleh hasil evaluasi lapangan, dimana peredaran kayu tanah milik tidak dapat dikontrol, sehingga sulit dibedakan dengan kayu yang berasal dari kawasan hutan.

IPKTM ini didominasi jenis jati yang dibedakan atas jati hasil budidaya dan jati bukan hasil budidaya. Besarnya tarif dari masing-masing jenis tersebut disajikan pada Tabel 1.

Berdasarkan uraian pada Tabel 1, maka dapat disimpulkan bahwa dalam rangka otonomi daerah ini muncul inisiatif yang kuat dari pemerintah daerah dan kalangan legislatif untuk melakukan pengaturanpengaturan pengelolaan sumberdaya hutan yang ada di wilayahnya. Namun demikian apabila dilihat dari Perda-perda yang dikeluarkan, upaya-upaya yang dilakukan untuk meningkatkan PAD sektor kehutanan adalah dengan cara memperbanyak jenis pungutan atas produksi hasil hutan, selain DR dan PSDH, serta peningkatan jenis dan besarnya tarif. Disamping itu upaya yang dilakukan adalah memperbanyak pemberian ijin dan penertiban peredaran hasil hutan dan lain-lain.

\section{Penjualan Lelang Kayu Jati}

Hasil penjualan lelang kayu jati yang dilaksanakan oleh Dinas Kehutanan Kabupaten Muna dimasukkan ke kas daerah yang merupakan nilai bruto dari pendapatan daerah.

\section{Penerimaan Pendapatan Sektor Kehutanan}

Dalam rentang waktu yang masih sangat mudah, otonomi daerah dihadapkan pada berbagai tantangan yang cukup berat. Salah satunya adalah kemampuan daerah dalam mempersiapkan berbagai infrastruktur pembangunan daerah, sehingga daerah berusaha semaksimal mungkin untuk memenuhi kebutuhan tersebut dengan cara meningkatkan penerimaan dari PAD. Otonomi daerah ini dilihat dari segi penerimaam, memberikan implikasi positif bagi peningkatan penerimaan PAD Kabupaten Muna.

\section{Penerimaan Bagi Hasil Pemerintah Pusat dan Daerah}

\section{Provisi Sumberdaya Hutan}

PSDH merupakan salah satu sumber pendapatan daerah Kabupaten Muna dengan perbandingan $20 \%$ Pemerintah Pusat, $16 \%$ Propinsi, $32 \%$ daerah penghasil dan $32 \%$ daerah lain dalam provinsi. Data penerimaan selengkapnya dapat dilihat pada Tabel 2. 
Tabel 2. Provisi pendapatan sumberdaya hutan di Kabupaten Muna

\begin{tabular}{rrrrrr}
\hline & & \multicolumn{4}{c}{ Proporsi penerimaan (Rp.) } \\
\cline { 3 - 6 } Tahun & Penerimaan (Rp.) & $\begin{array}{c}\text { Pemerintah pusat } \\
(20 \%)\end{array}$ & Propinsi $(16 \%)$ & $\begin{array}{c}\text { Daerah penghasil } \\
(32 \%)\end{array}$ & $\begin{array}{c}\text { Daerah lain dalam } \\
\text { propinsi }(32 \%)\end{array}$ \\
\hline 2000 & 121.074 .159 & 24.214 .832 & 19.371 .865 & 38.743 .731 & 38.743 .731 \\
2001 & 511.283 .386 & 102.256 .677 & 81.805 .342 & 163.610 .683 & 163.610 .683 \\
2002 & 776.659 .385 & 155.331 .877 & 124.265 .502 & 248.531 .003 & 248.531 .003 \\
2003 & 783.765 .985 & 156.753 .197 & 125.402 .558 & 250.805 .115 & 250.805 .115 \\
2004 & 765.335 .215 & 153.067 .043 & 122.453 .634 & 244.907 .269 & 244.907 .269 \\
\hline
\end{tabular}

Tabel 3. Pendapatan dana reboisasi di Kabupaten Muna

\begin{tabular}{crrrr}
\hline Tahun & Penerimaan (Rp) & $\begin{array}{c}\text { Daerah penghasil }(40 \%) \\
(\mathrm{Rp})\end{array}$ & $\begin{array}{c}\text { Pusat }(60 \%) \\
(\mathrm{Rp})\end{array}$ & $\begin{array}{r}\text { Persen pendapatan } \\
\text { dari tahun } 2000(\%)\end{array}$ \\
\hline 2000 & 229.489 .281 & 91.795 .712 & 137.693 .569 & \\
2001 & 974.718 .808 & 389.887 .523 & 584.831 .285 & 424,73 \\
2002 & 538.045 .892 & 215.218 .357 & 332.827 .532 & 234,45 \\
2003 & 1.222 .805 .231 & 489.122 .092 & 733.683 .139 & 532,84 \\
2004 & 354.298 .338 & 141.719 .335 & 212.579 .003 & 154,39 \\
\hline
\end{tabular}

Pada Tabel 2 dapat dilihat bahwa PSDH di Kabupaten Muna mengalami peningkatan yang sangat signifikan. Hal ini dapat dilihat pada penerimaan tahun 2000 (sebelum otonomi daerah) dengan penerimaan tahun 2001-2004. Pada tahun 2001 mengalami peningkatan sebesar $348,1 \%$ yaitu Rp 121.074.159 menjadi Rp 511.283.386 pada tahun 2001. Bahkan pada tahun 2002-2004, penerimaan rata-rata PSDH mencapai Rp 775.253.528 atau sekitar $640,31 \%$.

Peningkatan penerimaan tersebut antara lain disebabkan oleh banyaknya ijin usaha kehutanan yang dikeluarkan sehingga produksi hasil hutan juga meningkat. Disamping itu, tunggakan-tunggakan provisi sumberdaya hutan tahun sebelumnya telah dilunasi oleh pemegang ijin usaha kehutanan.

\section{Penerimaan Dana Reboisasi}

Penerimaan DR, juga merupakan salah satu sumber pendapatan daerah Kabupaten Muna disamping PSDH. Bagi hasil setoran DR adalah sebesar $40 \%$. Data penerimaan selengkapnya dapat dilihat pada Tabel 3 .

Pada Tabel 3 dapat dilihat bahwa penerimaan dari bagi hasil DR Kabupaten Muna mengalami peningkatan dari tahun ke tahun. Namun demikian peningkatan yang sangat signifikan dicapai pada tahun 2003 dan 2001, yaitu masing-masing 532,84 dan $424,73 \%$. Secara umum rata-rata peningkatan penerimaan setelah otonomi daerah adalah sebesar $336,60 \%$. Peningkatan penerimaan tersebut antara lain disebabkan oleh banyaknya ijin usaha kehutanan yang dikeluarkan sehingga produksi hasil hutan juga meningkat. Disamping itu, tunggakan-tunggakan DR tahun sebelumnya telah dilunasi oleh pemegang ijin usaha kehutanan.

\section{Penerimaan Pendapatan Daerah Murni}

\section{Penerimaan Retribusi Kayu}

Pemungutan retribusi hasil hutan kayu, dimulai sejak ditetapkannya 3 (tiga) perda pada tahun 2002 yaitu Perda Nomor 2, 3 dan 4. Atas dasar perda tersebut penerimaan retribusi hasil hutan kayu di Kabupaten Muna dimulai pada tahun 2002. Pemungutan retribusi hasil hutan kayu sebelum tahun 2002 dilaksanakan di Dinas Propinsi Sulawesi Tenggara. Data rencana dan realisasi penerimaan retribusi hasil hutan kayu disajikan pada Tabel 4 .

Tabel 4 menunjukkan bahwa penerimaan retribusi hasil hutan kayu memberikan kontribusi yang signifikan terhadap penerimaan asli daerah yaitu antara 1,5-3 Milyar thn-1. Jumlah penerimaan yang besar merupakan implikasi dari jumlah ijin yang diterbitkan. Pada tahun 2002 telah diterbitkan IPKTM sebanyak 48 ijin, tahun 2003 sebanyak 20 ijin, tahun 2004 sebanyak 19 ijin dan tahun 2005 sebanyak 36 ijin. ljin tersebut berlaku 6 (enam) bulan dan dapat diperpanjang untuk masa berlaku 3 (tiga) bulan.

\section{Penerimaan Lelang Kayu Jati}

Rencana dan realisasi penerimaan hasil penjualan kayu jati di Kabupaten Muna dapat dilihat pada Tabel 5. 
Tabel 4. Rencana dan realisasi penerimaan retribusi kayu

\begin{tabular}{|c|c|c|c|c|}
\hline \multirow{2}{*}{ Tahun } & \multicolumn{3}{|c|}{ Penerimaan retribusi } & \multirow{2}{*}{ Keterangan } \\
\hline & Rencana (Rp) & Realisasi (Rp) & Persentase (\%) & \\
\hline 2002 & 600.000 .000 & 1.556 .987 .400 & 259,50 & \\
\hline 2003 & 2.525 .500 .000 & 2.927.314.476 & 115,91 & \\
\hline 2004 & 2.225 .000 .000 & 2.892 .500 .000 & 130,00 & \\
\hline
\end{tabular}

Tabel 5. Rencana dan realisasi penerimaan hasil penjualan kayu jati di Kabupaten Muna

\begin{tabular}{|c|c|c|c|c|}
\hline \multirow{2}{*}{ Tahun } & \multicolumn{3}{|c|}{ Penerimaan } & \multirow{2}{*}{ Keterangan } \\
\hline & Rencana (Rp) & Realisasi (Rp) & Persentase (\%) & \\
\hline 2000 & 2.500 .000 .000 & 933.421 .205 & 37,33 & \\
\hline 2001 & 2.000 .000 .000 & 3.828.354.401 & 191,42 & \\
\hline 2002 & 7.290 .029 .000 & 7.792 .495 .000 & 106,90 & \\
\hline 2003 & 8.250 .000 .000 & 8.525 .330 .000 & 103,34 & \\
\hline 2004 & 6.500 .000 .000 & 9.484 .150 .000 & 145,91 & \\
\hline
\end{tabular}

Tabel 6. Kontribusi sektor kehutanan terhadap pendapatan asli daerah (PAD) di Kabupaten Muna

\begin{tabular}{cccccc}
\hline \multirow{2}{*}{ Tahun } & \multirow{2}{*}{$\begin{array}{c}\text { Penerimaan sektor } \\
\text { kehutanan }\end{array}$} & $\begin{array}{c}\text { Rencana } \\
(\mathrm{Rp})\end{array}$ & $\begin{array}{c}\text { Realisasi } \\
(\mathrm{Rp})\end{array}$ & $\begin{array}{c}\text { Persentase } \\
(\%)\end{array}$ & $\begin{array}{c}\text { Persentase penerimaan } \\
\text { sektor kehutanan } \\
\text { terhadap PAD }(\%)\end{array}$ \\
\hline 2000 & 1.626 .691 .133 & 6.592 .173 .138 & 8.313 .915 .689 & 126,11 & 19,57 \\
2001 & 5.796 .267 .927 & 11.330 .843 .378 & 16.324 .852 .186 & 144,07 & 35,51 \\
2002 & 11.500 .895 .598 & 20.608 .325 .053 & 27.561 .813 .116 & 133,74 & 41,73 \\
2003 & 14.347 .769 .648 & 27.640 .270 .470 & 33.681 .301 .593 & 121,85 & 42,60 \\
2004 & 14.424 .318 .086 & 35.578 .622 .828 & 36.766 .305 .931 & 103,34 & 39,23 \\
\hline
\end{tabular}

Tabel 5 menunjukkan bahwa penerimaan dari hasil lelang kayu jati memberikan kontribusi yang signifikan terhadap penerimaan asli daerah yaitu antara 0,9-9,5 Milyar thn ${ }^{-1}$ selama periode tahun 2000-2005. Pada tahun 2000 (sebelum otonomi daerah) realisasi penerimaan sebesar $37,33 \%$, sedangkan setelah otonomi daerah realisasinya antara $103,34-191,42 \%$.

\section{Kontribusi Sektor Kehutanan Terhadap Pendapatan Asli Daerah (PAD)}

Penerimaan sektor kehutanan sebelum dan setelah otonomi daerah dan kontribusinya terhadap PAD di Kabupaten Muna disajikan pada Tabel 6.

Pada Tabel 6 dapat dilihat bahwa kontribusi sektor kehutanan terhadap PAD Kabupaten Muna pada tahun 2000 (sebelum otonomi daerah) sebesar $19,57 \%$. Sedangkan setelah otonomi daerah (tahun 2001-2004) memberikan kontribusi yang cenderung meningkat dari tahun ke tahun yaitu berkisar antara $35,51-42,60 \%$ dengan rata-rata sebesar $36,77 \%$.
Upaya-upaya yang dilakukan oleh Pemerintah Kabupaten Muna memberikan hasil yang sangat signifikan terhadap PAD. Upaya tersebut berupa pemberian ijin usaha kehutanan yang ditetapkan melalui Peraturan Daerah, penagihan tunggakan dana-dana reboisasi dan PSDH, serta penerapan aturan yang ketat terhadap pelaku illegal logging.

\section{KESIMPULAN}

Berdasarkan hasil penelitian dan pembahasan yang telah diuraikan pada bagian terdahulu, maka dapat disimpulkan sebagai berikut:

1. Sektor kehutanan memberikan kontribusi yang signifikan terhadap peningkatan PAD rata-rata $36,77 \%$ per tahun.

2. Penerimaan sektor kehutanan berasal dari iuran $\mathrm{DR}, \mathrm{PSDH}$, pemberian ijin usaha kehutanan dan hasil penjualan lelang kayu jati. 


\section{DAFTAR PUSTAKA}

[Dephut] Departemen Kehutanan. 1999a. Undang-Undang Republik Indonesia Nomor 41 Tahun 1999 tentang Kehutanan. Kopkar Hutan. Jakarta.

1999b. Undang-undang Republik Indonesia Nomor 22 Tahun 1999 tentang Pemerintahan Daerah.

1999c. Undang-undang Republik Indonesia Nomor 25 Tahun 1999 tentang Perimbangan Keuangan antara Pemerintah Pusat dan Daerah.

[Dephut] Departemen Kehutanan. 2000. Undang-undang Republik Indonesia Nomor 25 Tahun 2000 tentang Kewenangan Pemerintah dan Kewenangan Propinsi sebagai Daerah Otonom.
Lappy, M. 2001. Tinjauan Terhadap Pelaksanaan Pemberian Otonomi Daerah kepada Pemerintah Daerah Kabupaten Gowa. Universitas Hasanuddin, Makassar.

Simanjuntak, R.A. 2001. Melaksanakan Otonomi Tidak Mudah. Wacana Alumni Diklat LPEM Fakultas Ekonomi Universitas Indonesia Volume II No.4 Oktober 2001. LPEM-UI.Jakarta.

Syaukani, 2000. Menatap Harapan Masa Depan Otonomi Daerah. Gerbang Dayaku Offset and Printing. Tenggarong.

Wiyono and S.A. Awang. 2001. Konsep Pemerintah Daerah Kabupaten Wonosobo tentang Pengelolaan Sumberdaya Hutan dalam rangka Otonomi Daerah. Jurnal Hutan Rakyat Volume III Nomor 3 Tahun 2001. Pusat Kajian Hutan Rakyat Universitas Gadjah Mada. Yogyakarta. 